\title{
UNDERSTANDING TELETANDEM LANGUAGE LEARNING FROM AN INTERSUBJECTIVE PERSPECTIVE
}

\author{
A aprendizagem de línguas em teletandem sob uma \\ perspectiva de intersubjetividade
}

Gerson Rossi dos SANTOS 1

Douglas Altamiro CONSOLO²

\begin{abstract}
This paper is about an investigation on language description that focuses on the role of the establishment of intersubjectivity (MCCAFFERTY, 2002; MORI; HAYASHI, 2006; VYGOTSKY, 1995; DURANTI, 2010; SAMBRE, 2012) in the teletandem learning process. Intersubjectivity is understood as an experience of otherness between discourse subjects and is established between individuals as they recognize each other as individual subjects in social contexts. We report on analyses of teletandem data from one online interaction within the project Teletandem: transculturality in online interactions via webcam (TELLES, 2011). The data were generated in a context of institutional and integrated teletandem interactions (CAVALARI; ARANHA, 2016). The oral sessions were audio and video-recorded. The recordings were transcribed and analyzed according to a hermeneutic orientation. The categories focused in the study contemplate (i) verbal and non-verbal communication, (ii) the co-construction of conditions for responsiveness in the target-language; (iii) bodily mimesis; as well as (iv) the co-construction of a shared framework of reference. Among other findings, the establishment of intersubjectivity encompasses both an immediate partner-to-partner dimension as well as a broader discourse community-based dimension. It has shown to develop as partners perceive each other aesthetically through their voice and cinematic image, so that they can develop mutual responsiveness.
\end{abstract}

Keywords | Intersubjectivity. Language Education. Teletandem. Hermeneutics. Phenomenology.
Resumo | Este artigo consiste no recorte de uma investigação em descrição linguística que enfoca o papel do estabelecimento de intersubjetividade (MCCAFFERTY, 2002; MORI; HAYASHI, 2006; VYGOTSKY, 1995; DURANTI, 2010; SAMBRE, 2012) no processo de aprendizagem de línguas em teletandem. A intersubjetividade é compreendida como a experiência de alteridade vivenciada pelos sujeitos do discurso e é estabelecida entre eles na medida que reconhecem um ao outro como indivíduos inseridos em contextos sociais. Baseamo-nos na análise de dados de uma amostra correspondente a uma interação on-line em teletandem, no escopo do projeto Teletandem: a transculturalidade das interações on-line em línguas estrangeiras via teleconferência (TELLES, 2011). Os dados foram gerados no contexto de Teletandem Institucional Integrado (CAVALARI; ARANHA, 2016). As sessões orais foram registradas em áudio e vídeo e, então, transcritas e analisadas segundo orientação hermenêutica. As categorias levantadas abrangem (i) a comunicação verbal e não verbal; (ii) a co-construção de condições de responsividade na língua meta; (iii) mimese corporal e (iv) a co-construção de um quadro de referências compartilhado entre os participantes. Entre os achados, verificou-se que o estabelecimento de intersubjetividade compreende tanto a dimensão imediata entre os parceiros quanto uma dimensão maior, fundamentada na comunidade discursiva a que se reconhecem pertencer. Verificou-se, também, que a intersubjetividade tende a se desenvolver na medida que os participantes reconhecem-se esteticamente por meio da voz e da imagem de webcam de modo que possam desenvolver responsividade mútua.

Palavras-chave | Intersubjetividade. Desenvolvimento Linguístico. Teletandem. Hermenêutica. Fenomenologia.

\footnotetext{
1 Santos. IFSP. E-mail: gersonrossi@hotmail.com. ORCID ID: https://orcid.org/0000-0002-7442-4354 
- | Understanding teletandem language learning from an intersubjective perspective

\section{Introduction}

From the perspective of intersubjectivity, communication and discourse take place properly when it comprises the aspect of otherness that allows subjects to recognize each other as such, as well as the recognition of their selves. Intersubjectivity and thus language development can be well established when teachers (and/or other actors in a learning context, for example, peer students) make their linguistic and genre choices motivated by their perception and recognition of the other. This perspective is supported by the assumption (from both a scientific and a philosophical perspective) that otherness understood as the intentional activism of the self towards the other as an equal individual person - might operate on mutual recognition so that communication and language development can be facilitated.

This aim of this article is to demonstrate how intersubjectivity can be observed in a context of teletandem language learning, to propose a few analysis categories and reflect on the impact of these categories upon the quality of oral interactions and the opportunities for developing language proficiency. In order to do so, we report on analyses of teletandem data from one online interaction within the project Teletandem: transculturality in online interactions via webcam (TELLES, 2011). The data were generated in a context of institutional integrated teletandem interactions (ARANHA; CAVALARI, 2014; CAVALARI; ARANHA, 2016), involving one practitioner from a language teacher education course in Brazil and one Portuguese as a foreign language student in a university in the USA. A more detailed definition of 'teletandem' is presented in the next section of this article.

The Brazilian teletandem practitioner was in her last year of a teacher education course that aimed at educating future teachers of the Portuguese and the English languages so that those teacher-candidates would be certified to teach in contexts of basic (primary and secondary) schools, as well as in language schools in Brazil. The undergraduate student's experience in institutional integrated teletandem interactions, that is, teletandem sessions conducted as part of the language education program in Brazil, is expected to contribute towards her language development so that she will be linguistically competent to use the English language in her future lessons. This is the connection we intend to establish in this article, a connection between intersubjectivity in teletandem interactions and future teachers' foreign language development.

In the following sections, we present a theoretical review on intersubjectivity and an explanation of teletandem contexts, followed by an analysis of teletandem data and intersubjectivity, and some final remarks about our reflections on these topics. 


\section{Intersubjectivity}

Intersubjectivity can be broadly understood as the social phenomenon of mutual recognition between subjects through the languages (both verbal and nonverbal) they use in order to communicate. However, the concept of intersubjectivity is not yet consensually defined. It is often referred to in Phenomenological Philosophy, Developmental Psychology, Linguistics and Cognitive Semiotics, as well as other areas such as Neuroscience, Social Sciences, Anthropology, and Education, to name a few. In Applied Linguistics, it has become of an increasing concern despite the fact that studies on intersubjectivity in this area are relatively scarce.

For instance, studies by Mori and Hayashi (2006) describe how Japanese learners of English as a second language (L2) develop mutual repertoires of gestures to boost communication in that language. Besides mapping how gestures are established by pairs of learners as a common exclusive frame of reference to overcome occasional comprehension gaps, the authors also outline the practice of hybrid interactional moves, understood as the combination of verbal and non-verbal language, to provide each other evidence of comprehension and/or non-comprehension, thus enabling intersubjectivity to improve between the learners.

In a similar study, McCafferty (2002) investigates the co-construction of what the author calls a tool kit between L2 learners to overcome communication obstacles. According to the author, L2 learners under investigation co-construct a set of common resources, including body language, to turn to when they face difficulties in uttering verbally, thus enhancing their interpersonal territory and improving conditions of mutual comprehension and language development.

In these perspectives - set within studies in Applied Linguistics -, intersubjectivity is seen as a scaffolding resource to further language development. Once learners of an L2 may share different language backgrounds and/or language proficiency, the establishment of intersubjectivity - in which gestures are considered to play a central role - can ground communication while verbal discourse is developed.

However, the concept prior refers to the phenomenological branch of philosophy, especially in the works of Husserl (1969), Scheler (1971) and Merleau-Ponty (1996), among others, in pursuing a philosophical approach to understanding the constitution of the individual subjectivity, that is, the self-recognition of the person as an individual subject. There is an actual consensus that the self is only recognized after the individual intentionally and actively recognizes the other both aesthetically and ethically. Under this assumption, 
- | Understanding teletandem language learning from an intersubjective perspective

the subject is constituted socially before it develops an individual dimension (as opposed to Cartesian views).

Nonetheless, the phenomenological view of subjectivity - which is intersubjective by constitution - faces challenging implications, such as understanding how (in operational terms) the self experiences a foreign consciousness considering that immediate access to the other is unlikely. Philosophical solutions offered as answers to this problem include the processes of intropathy, analogical inference and subject transcendence. Intropathy refers to the mutual recognition of intentions and motivations manifested as specific language behavior and/or ethical orientation; analogical inference consists of perceiving from the bodily actions of others that they participate and experience the same concrete (and/or physical) phenomena as the self, so that they can recognize each other as equals; subject transcendence is conceived as an intentional activism towards participating in the other's experience. In sum, intersubjectivity is fundamentally associated to otherness, that is, in understanding one's own experience as extensive to another person's.

Phenomenological philosophy also understands the body as the aesthetic expression of the self, which means that individuals express themselves and recognize the other by means of how the body allows them to be aesthetically perceptual to the other, and vice-versa. Much of such recognition process occurs in the field of resemblance, that is, in the perception that bodily dynamics are similar among persons, which provides an evidence of similarity, equality and thus empathy - the principles of analogical reference.

Agreeing with Husserlian studies, Bakhtin (2015) suggests that the body holds the first dimension of dialogue in terms of emotional-volitional communication, between a baby and the mother, for instance. Moreover, the author assumes that the self is composed by both an interior body and an exterior body. The interior body is a dimension of selfexperience - one with very important limitations for the constitution of the self. The exterior body is the physical perception of the other, which includes perceiving edges that shape the other as physically individual, delimited from the surrounding background and thus dynamically situated in the world - from a plastic-pictorial perspective. According to the author, the ego can only perceive itself as an individual through its exterior body - that is, the aesthetic appreciation of the other - and never from their interior body experience. Both in Phenomenology and Language Philosophy made by Bakhtin, intersubjectivity occurs as the body is perceived as an aesthetic expression, and subject transcendence allows a condition of otherness. 
From these initial assumptions, the comprehension of intersubjectivity allows two (non-opposed) directions: one of an operational nature, to describe how intersubjectivity is established; and another, rather metaphysical, that pursues the relation between intersubjectivity and language, as well as language development and the development of linguistic proficiency.

In order to continue with the operational aspect of this discussion, for the cognitivist semiotic works of Zlatev (2007, 2008), Meltzoff and Brooks (2007) and Möttönen (2016), among others, the establishment of intersubjectivity is associated to the mutual development of verbal language, but not only. According to this view, verbal discourse development is preceded by bodily schemas and bodily mimesis: the former is related to body actions that are considered to be non-communicative (or at least unintentionally communicative) like blinking, yawning, sneezing and so forth; the latter is related to body action intentionally oriented to communicate, either on the iconic level (for example, moving an empty spoon towards the mouth to mean hunger, or moving hands in a hectic pace to mean hurry); or on the indexical level (for example, pointing a finger out towards a person or a place, for social reference or for a direction). Verbal language is considered a post-mimetic level of intersubjectivity, as the following extract from Zlatev (2008, apud MÖTTÖNEN, 2011) suggests. According to the author, studies reveal five levels of intersubjectivity, such as:

1. Proto-mimesis: associated e.g. with neonatal imitation, mutual attention and 1st order mentality

2. Dyadic mimesis: shared attention, understanding of other's intentions, 2nd order mentality (understanding others through projection)

3. Triadic mimesis: joint attention, having and understanding communicative intentions, 3rd order mentality (attention and intentions)

4. Post-mimesis1/protolanguage: semantic conventions, 3rd order mentality (expectations)

5. Post-mimesis2/language: (false) belief understanding, 3rd order mentality (beliefs) (p. 151) 
- | Understanding teletandem language learning from an intersubjective perspective

One important assumption from this perspective is that the verbal dimension of language is grounded in other levels of intersubjectivity, other ways in which subjects mutually transcend the individual domain towards otherness for their own constitution.

In the metaphysical field, a consistent definition of language refers to the debates proposed by Heidegger (2007) and Benjamin (2015). According to these perspectives, language expresses itself and is understood as a broad universal phenomenon in which everything - and everyone - expresses itself and himself. Similarly, in verbal discourse, understood as a type of language singularly manifested at the word level, speakers express themselves as they participate in discourse by no other means but dialogue (see, for example, Bakhtin, 2015).

In summary, L2 learners who seek for the development of verbal proficiency (because they do not share that competence) are allowed to ground their learning on other dimensions of language, all dimensions in which intersubjectivity is considered to occur. So if L2 learners face obstacles in communicating verbally to each other (dialogically - which means uttering, rather than simply producing sentences that would be clearly understood regardless of their communicative purpose within a dialogue), other levels of intersubjectivity may keep communication active and preserve opportunities to develop language at the discourse level.

The other - as opposed to the self - is not necessarily considered an individual. A definition of the other may also refer to whole communities, their culture, their history and their social organization. On this dimension, the individual transcends towards the collective other as a process of affiliation. The two dimensions of otherness - both individual and plural - are critical to constitute the intersubjective person and their communication competences. Otherness is not only the recognition of an immediate interlocutor. Also, it is the recognition of communities of individuals to which it is possible to self-consider a member - which is the case for the development of specific verbal languages and social varieties (for example, Brazilian Portuguese, European Portuguese, Southern Brazilian Portuguese, American English, British English, Black English and son on).

Discourse and dialogue as approached from the intersubjective perspective refer to the concepts of Bakhtin's dialogism. In the author's view, communication takes place as individuals produce utterances - understood as the concrete unit of discourse (see, for example, Bakhtin, 2006). An utterance, to this view, encompasses both conditions of conclusibility and the alternation of speech subjects: the former assumes that utterances are regarded as such as the individuals involved in communication mutually recognize its conclusibility; the latter corresponds to the assumption that every utterance is responsive 
to another - either an individual or a collective other - and is similarly produced to cause response. The conclusibility of an utterance is related to the possibility of (i) understanding its theme to the comprehensive level (semantic exhaustion); and (ii) understanding the speaker's intention, and (iii) recognizing the employed discourse genre. According to the author, since these conditions are met, the other can understand the utterance as concluded and be responsive to the utterance so that speech subjects alternate and the dialogue chain continues to develop. Thus, the concept of utterance is fundamentally based on the experience of reciprocity and intersubjectivity.

\section{What is teletandem?}

'Teletandem' contexts involve pairs of native or non-native speakers of different languages working collaboratively to learn each other's language. For example, Brazilian university students who study a foreign language and wish to develop their proficiency in this language, paired with students in other countries who are learning Portuguese. With tandem language learning, each partner is a student for one hour, learning and practicing a language from the other partner. Then they switch roles and switch languages.

Teletandem may be defined as a process of cooperative language learning by means of electronic communication. In a teletandem partnership, students are expected to help each other learn the languages in which they are proficient users.

Interactions in teletandem contexts are grounded on the principle of learner autonomy, that is, language learning is no longer the responsibility of a class teacher alone. Learners are responsible for their own process of language learning, and this responsibility requires that learners decide about their learning goals, the content of learning and the resources to be used. In this sense, learners benefit from the possibility of negotiating the aforementioned aspects with their partners - that is, decisions that can contribute - or not - to the success of a collaborative language learning experience, or that can possibly reduce the benefits of the teletandem experience, are the agents' prerogative.

Teletandem interactions occur by means of online chat, audio or video communication, with the help of communication devices and software such as Skype and Zoom, and generate a corpus of written and spoken data. Focusing on spoken language and for research purposes, oral data has been recorded by means of a software called Easy Recorder, which is available on the internet, free of charge. 
- | Understanding teletandem language learning from an intersubjective perspective

A full teletandem session usually lasts two hours. One hour is dedicated to each of the two languages used by the practitioners. In principle, each one-hour session comprises three parts: (a) conversation, (b) feedback on language and (c) evaluation of the session. In the first part of the session, the students engage in a conversation in the target language, about one or more topics, for around thirty minutes. In the second part, which takes approximately twenty minutes, the practitioners discuss the language used in their previous conversation and the most proficiency agent has the opportunity to provide linguistic feedback to his or her partner. The feedback is given with the help of notes written during the conversation or, in the case of written communication (chat), by referring to the previous lines of their interaction. The third part of the session lasts around ten minutes and is dedicated to evaluating the whole session, comprising a discussion about the difficulties faced by the participants while interacting in teletandem and suggestions for future action. Once the agents have completed an interaction period at least eight to twelve weeks, they may decide to continue or to end their partnership.

Before the 8-week period, both the foreign and the Brazilian practitioners are given instructions and orientations about TTDii by means of a tutorial session. On that occasion, each language teacher provides their respective teletandem group (in each country) with a calendar of activities, theoretical principles and instructions about practical procedures, as well as strategies on how to benefit from the work. Practitioners are also invited to verify their level of target language proficiency by means of self-assessment scales, and to set their learning goals accordingly.

\section{What do Teletandem data indicate about intersubjectivity?}

The teletandem interactions that constitute data in this study were audio and video-recorded as participants engaged in online conversations through Skype, making use of webcams. The recordings were then transcribed and analyzed by means of qualitative procedures - from a hermeneutic-methodological perspective - combined with quantitative procedures.

The hermeneutic perspective aims at approaching language learning in this context as a historical experience of participants seen as ever-ongoing constructing subjects. Quantitative procedures, on the other hand, are taken exclusively for mapping the events raised by qualitative interpretation along visual timelines, so that comparing different aspects of the qualitative analysis could be possible. 
The categories focused in the study contemplate verbal and non-verbal communication, the fact that the practitioners are establishing the grounds for reciprocal language learning, and variations in discourse genres.

Interactions in a context of institutional integrated teletandem (TTDii interactions) observed in this preliminary analysis are held by Isabela - an undergraduate student of English and Portuguese in a Brazilian university, and also a language teacher-candidate in the context of a Letters course - and Sally - an undergraduate student of Portuguese in a university in the USA, in the context of a major unrelated to Education. TTDii means that an academic agreement was established between the Brazilian university and the university in the USA so that all the students from one class of the Letters course in Brazil were supposed to interact with a whole class of students who were learning Portuguese at the university in the USA. Conversely, the teletandem interactions were thus 'institutionalized' and 'integrated' in the course programs of both classes.

The sample data used in this analysis corresponds to their first interaction session (29 minutes and 26 seconds in length, transcribed in 294 turns) and therefore, their first contact with each other as well as their first teletandem experience. According to TTDii instructions, they were supposed to meet online weekly for a two-month period. The data analysis conducted in this study was based on the recording of the first interaction session.

In these initial circumstances, data show that participants resort mostly on a dimension of intersubjectivity related to the collective other (as opposed to the individual other) to establish communication: they recognize each other as members of communities based on a particular discourse and a particular social, cultural and historical background, so their linguistic choices (what they say and how they say) are motivated by the urge to keep the conversation active and meet formal teletandem instructions. In the sample below, from the beginning of an oral session, practitioners negotiate which language to start with (either English or Portuguese) as well as the written text correction, both actions comprised by the formal TTDii instructions the had been given before the first oral session. In the utterances, neither language negotiation nor topics of mutual interest can be seen, but actions to keep the activity organized accordingly. 
- | Understanding teletandem language learning from an intersubjective perspective

\section{Excerpt 1}

\begin{tabular}{llll}
\hline Turn & Speaker & Utterance & Notes \\
\hline $\mathbf{1 9}$ & Isabela & $\begin{array}{l}\text { você quer: começar falando em português ou } \\
\text { em inglês? }\end{array}$ & \\
\hline $\mathbf{2 0}$ & Sally & $\begin{array}{l}\text { ahm + + it doesn't matter + whatever you } \\
\text { wanna do [riso] }\end{array}$ & \\
\hline $\mathbf{2 1}$ & Isabela & $\begin{array}{l}\text { pode ser português então? ++ pode/ a gente } \\
\text { pode começar com português aí depois a } \\
\text { gente troca pra inglês? }\end{array}$ & $\begin{array}{l}\text { Sally switches } \\
\text { from a mostly } \\
\text { smiling } \\
\text { expression } \\
\text { to a serious } \\
\text { expression }\end{array}$ \\
\hline $\mathbf{2 2}$ & Sally & ahm + sim & \\
\hline $\mathbf{2 3}$ & Isabela & tá bom & \\
\hline $\mathbf{2 4}$ & Sally & ahm tá bom & \\
\hline $\mathbf{2 5}$ & Isabela & então + eu não recebi a sua redação & \\
\hline
\end{tabular}

It is also assumed that no intersubjective territory has been constructed particularly between the two participants (as individuals) prior to their first interaction. Conversation topics (what they choose to talk about), in these circumstances, are almost exclusively selected by the Brazilian participant under two basic observable types of motivation: (i) responsivity internal to the partnership, which refers to a turn whose topic selection is, by surface evidence, motivated by the contents of the previous turn (i.e. by what the interlocutor said), and (ii) responsivity external to the partnership, which refers to a turn whose topic selection presents no surface evidence of motivation by the contents of the previous turn (i.e. it is likely organized to meet other type of uttering motivation such as to keep the conversation going, among others). A sample of these aspects can observed in excerpt 2 below: 


\section{Excerpt 2}

\begin{tabular}{|c|c|c|c|}
\hline Turn & Speaker & Utterance & Notes \\
\hline 163 & Isabela & $\begin{array}{l}\text { ahm this city where is my university is the same } \\
\text { city that I live I was born in this city São José } \\
\text { do Rio Preto + and the university is very close } \\
\text { of my/ of my house + is five minutes by car + } \\
\text { so it's very close + and I live with/ and I live } \\
\text { with my parents + eh + but I didn't have sisters } \\
\text { or brothers but I/ when I was a child I want/ I } \\
\text { wanted very much to have sisters and brothers } \\
\text { + but + I don't have }\end{array}$ & \\
\hline 164 & Sally & oh [riso] ++ but you can have false friends & \\
\hline 165 & Isabela & $\begin{array}{l}\text { yes + very close friends ++ but when I was a } \\
\text { child I want to: + play with my/ with sisters and } \\
\text { brothers not only with + friends + and I asked } \\
\text { for my mother give me a brother but when } \\
\text { my mother didn't give me brothers and sisters } \\
\text { [laugh] }\end{array}$ & $\begin{array}{l}\text { Interlocutor } \\
\text { smiles back. }\end{array}$ \\
\hline 166 & Sally & $\begin{array}{l}\text { yeah I've my three older sisters and + they've } \\
\text { always been my best friends so I don't know } \\
\text { what I would do + as an only child I could not } \\
\text { do it [laugh] }\end{array}$ & \\
\hline 167 & Isabela & $\begin{array}{l}\text { yes + when I was child I didn't like so much be a } \\
\text { only child but now I/ I like + I + + how I can say: } \\
\text { + eu estou acostumada? [ I am used to it? ] }\end{array}$ & \\
\hline 168 & Sally & + you're accustomed to it + you're used to it & \\
\hline 169 & Isabela & [yes + yes + yes & \\
\hline 170 & Sally & $\begin{array}{l}\text { + you get/ you get more attention from your } \\
\text { parents probably [laugh] }\end{array}$ & \\
\hline 171 & Isabela & yes + yes & \\
\hline 172 & Sally & they just spend all their time [laugh] & \\
\hline 173 & Isabela & ye:s & \\
\hline 174 & Sally & $\begin{array}{l}\text { is that ever annoying? Do they bother you too } \\
\text { much? }\end{array}$ & \\
\hline 175 & Isabela & yes $[$ laugh $]$ & \\
\hline
\end{tabular}


- | Understanding teletandem language learning from an intersubjective perspective

\begin{tabular}{|c|c|c|c|}
\hline 176 & Sally & [laugh] & \\
\hline 177 & Isabela & + & \\
\hline 178 & Sally & So do you live at home with them still? & \\
\hline 179 & Isabela & "watch"? & \\
\hline 180 & Sally & you / do you live at home with them still? & \\
\hline 181 & Isabela & $\begin{array}{l}\text { yes + I live because I don't have a "jobe" + } \\
\text { because my university is all the day + in the } \\
\text { morning and in the afternoon so I/ I/ I worked } \\
\text { two lat/ two years + before + e:h + but work for } \\
\text { me is very difficult because I study all the day so } \\
\text { I didn't have a job and I didn't can have my own } \\
\text { house + because }\end{array}$ & \\
\hline 182 & Sally & [oh yeah + no & \\
\hline 183 & Isabela & $\begin{array}{l}\text { because it's difficult and I think that this is very } \\
\text { expensive }\end{array}$ & \\
\hline 184 & Sally & $\begin{array}{l}\text { yeah it's really expensive }+ \text { I would live at home } \\
\text { if I could + but it's just too far + because }+ \text { there } \\
\text { are other universities closer and I could live at } \\
\text { home but this school is better }\end{array}$ & \\
\hline 185 & Isabela & o:h ok & \\
\hline 186 & Sally & + better to go to + to get a job & \\
\hline 187 & Isabela & $\begin{array}{l}\text { but I want to have my own house and have } \\
\text { one "jobe" and be a teacher and be rich in the } \\
\text { future [riso] + and have my house and + my } \\
\text { family + because live with my parents is very } \\
\text { difficult because I don't have my/ my time and } \\
\text { + sometimes my parents are very: + I don't know } \\
\text { they interfere so much in my life + I didn't can } \\
+ \text { can + decide my/ my things my/ I didn't have } \\
\text { my ideas because all I/ I do is with my parents + } \\
\text { so: this is very difficult }\end{array}$ & $\begin{array}{l}\text { Interlocutor } \\
\text { smiles back. }\end{array}$ \\
\hline 188 & Sally & Yeah & \\
\hline 189 & Isabela & $\begin{array}{l}\text { [I don't know but do you understand? it's very } \\
\text { difficult + for me + I love live with my parents } \\
\text { but sometimes my mother is very protec/ I } \\
\text { don't know + protetora + he protect }\end{array}$ & \\
\hline
\end{tabular}




\begin{tabular}{lll}
\hline 190 & Sally & [protective \\
\hline 191 & Isabela & $\begin{array}{l}\text { yeah + he protects a lo:/ a los me + so this is } \\
\text { difficult for me }\end{array}$ \\
\hline 192 & Sally & $\begin{array}{l}\text { uhum }++[\text { riso] it sounds difficult ahm + they } \\
\text { just / yeah I can imagine + I was ready to leave } \\
\text { I left ahm after high school so + when I was } \\
\text { eighteen + I moved/ I moved up here }\end{array}$ \\
\hline $\mathbf{1 9 3}$ & Isabela & Ok \\
\hline $\mathbf{1 9 5}$ & Sally & $\begin{array}{l}\text { [but I see them + I mean I just see them like } \\
\text { every other weekend + every two weeks }+ \text { and } \\
\text { now I probably seem them once a month }\end{array}$ \\
\hline $\mathbf{1 9 6}$ & Sally & ah ok ++ yeah \\
\hline
\end{tabular}

Data show that when there is surface evidence that the topic initiated at one turn is motivated by the content(s) of the previous turn, the topic takes a larger amount of turns and is maintained for a longer extent of the conversation, and that discourse and communication are kept active as well. Excerpt 2, above, is a sample of such internal responsivity. On the other hand, topics initiated by rather an external responsivity move take fewer turns and tend to end shortly (aspect observable in excerpt 1). This information not only does reinforce the hypothesis that intersubjectivity and communication develop along with immediate otherness, but it also explores the operational aspect of responsivity quality over turn-taking dynamics.

For instance, 41 events of topic selection were recognized among the 294 total turns of the interaction session (i.e. participants changed their conversation topic 41 times). Sixteen of them are considered externally responsive (motivation type II) whereas the remaining 22 are categorized as motivated by internal responsivity (motivation type I). In the chart in figure 1 below, all events of topic selection are represented by squares and triangles over the full interaction timeline depending on the type of motivation they are related to. 
- | Understanding teletandem language learning from an intersubjective perspective

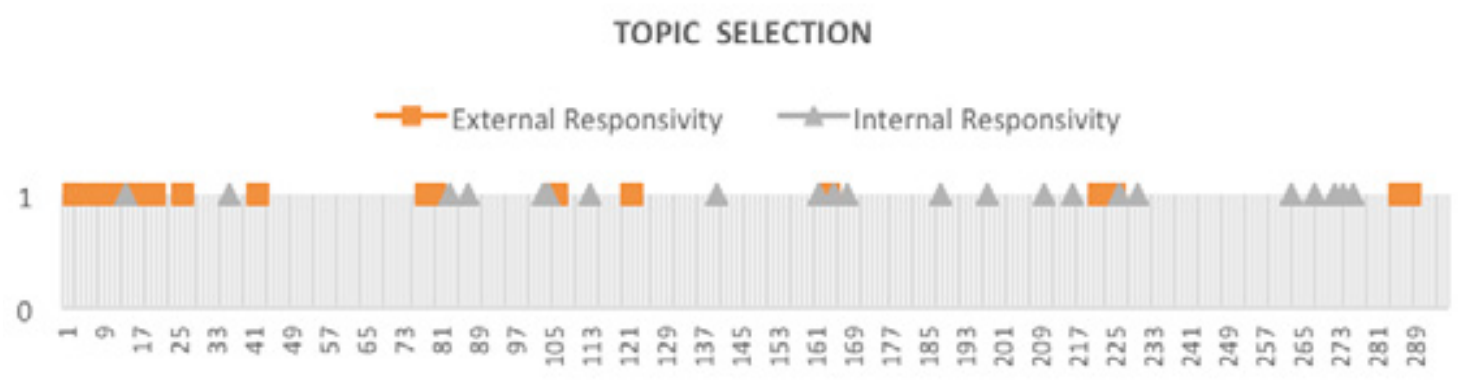

Figure 1. Turns and length of topic maintenance and change

Squares (type II - non-immediate responsivity) prevail in the initial turns of the conversation, where the short distance between one square and the next indicates that topics are ended briefly, so another topic is selected. With the passing of time (for example, from turn 78 forth), the longer distance between squares and triangles (represented by a straight line not covered by any form) reinforces the qualitative observation that participants maintain the conversation topics for longer without being motivated to select a new one (or losing conversational interest on a given topic). On the other hand, triangles (type I - immediate responsivity) prevail from that moment on, indicating that, as time passes, participants develop a rather immediate kind of responsivity to one another - as an individual-based experience of otherness - and resort less often on external responsivity as a community-based experience of otherness. Moreover, triangles are more commonly followed by longer straight lines, which means topics tend to be more stable when initiated by internal responsivity. In fact, a qualitative interpretation of the interaction suggests that personal interest in a given topic is higher when its reference is mutually shared (that is, initiated internally) - and is not chosen apparently at random. For example, turn duration - the length of time one participant holds the speech turn - is increased within periods in which internal responsivity is more common, as illustrated in the chart in figure 2 below: 


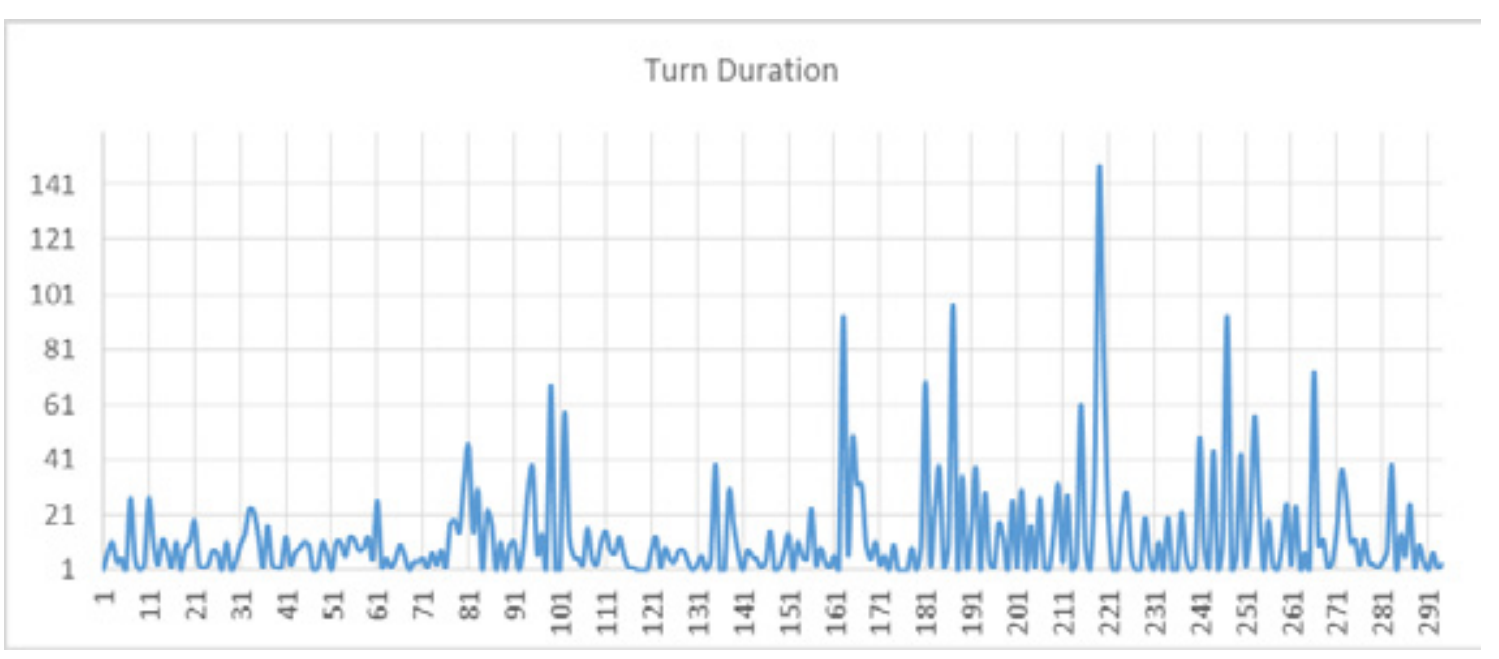

Figure 2. Turn duration

When information on topic maintenance and change, as shown in figure 1, is compared to the graph in figure 2 , one realizes that turn duration peaks range over the same extent of the interaction in which internal responsivity prevails. That is, topic maintenance and turn duration are related to responsiveness and how it operates - either internally or externally. In other words, the way one participant responds to the other shows to have an impact over how long utterances become (and possibly the constructed participant's interest in it) and for how long they keep the same conversation topic (without changing it).

Three basic categories of discourse expression can be raised under the technicalmethodological conditions in which TTDii activity takes place: (i) segmental (i.e. verbal communication that can be heard and transcribed); suprasegmental (i.e. prosodic components of verbal expression) and; (iii) paralinguistic (i.e. non-verbal expression that can be seen and categorized, both intentionally oriented to communicate - e.g. bodily mimesis - and unintentionally oriented to communicate - e.g. mimetic schemas). Furthermore, these categories can be perceived as part of the phenomenon of mutual aesthetic recognition, which, in the context of TTDii, encompasses both the visual and hearing perception of the other, as illustrated below:

At the non-verbal dimension of communication, synchronic cinematic image exchange via webcam in TTDii interactions is a technical feature that allows the aesthetic recognition of the other at the visual level both by means of composition and mimetic variability ${ }^{3}$. Composition refers not only to what elements are included within the borders of the image capture but also to how the subject (the other participant) is pictorially

3 During oral sessions, participants can see their partner's as well as their own image on the computer screen. 
- | Understanding teletandem language learning from an intersubjective perspective

contextualized. Mimetic variability refers to how body language is employed, either intentionally or unintentionally, in paralinguistic communication (e.g. how their moves relate to what they say). At the hearing level, participants perceive each other as segmental and suprasegmental articulation varies. Variation in the three levels - segmental, suprasegmental and paralinguistic - has shown to perform an important role in the quality of communication.

Qualitative interpretation combined with quantitative procedures show that the more varied body language is, the better the communication conditions concerning mutual comprehension and turn-taking dynamics are, especially considering the participants' expression of empathy via webcam. In order to illustrate that visually, the chart in figure 3 below indexes of mimetic variation are compared to occurrences of topic selection under both internal and external responsivity:

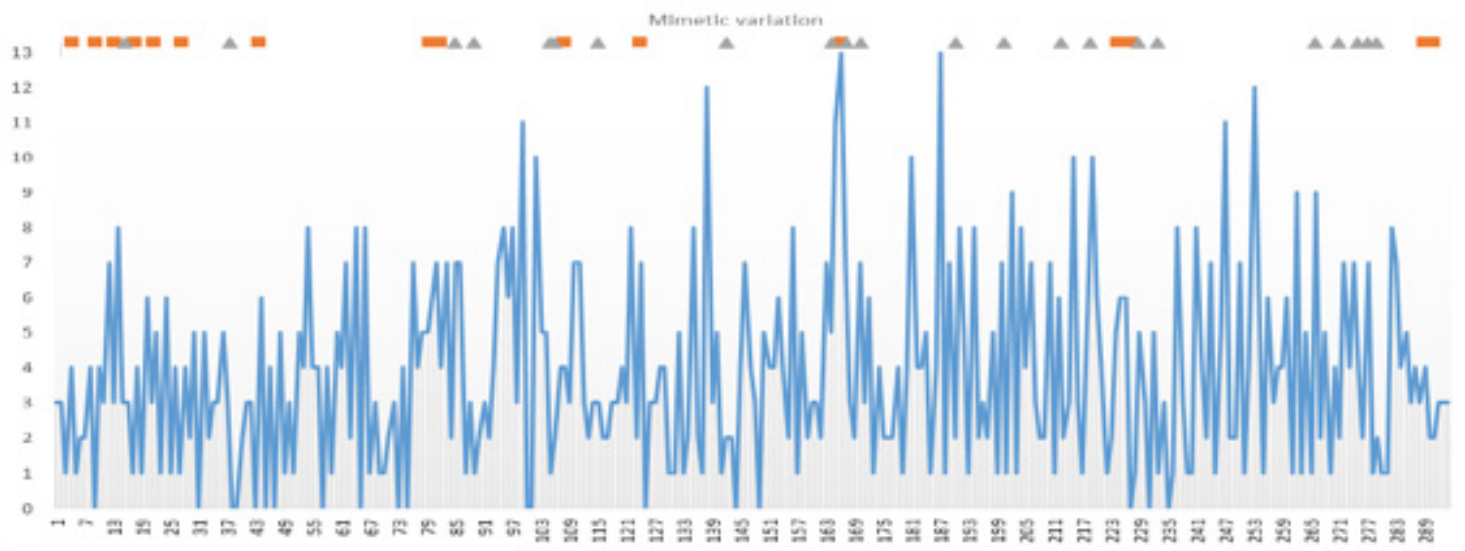

Figure 3. Mimetic variation

As in the chart in figure 1, squares refer to topic selection externally motivated and triangles to topic selection rather related to an internal type of responsivity (similar to the information in figure 1). The blue line represents the mimetic variation of participants' interactive actions over the oral session, which is curved towards the predominance of triangles, and indicates an association between body language variation, immediate responsivity and the quality of communication.

Most of the mimetic variation observed via webcam accounts for eye orientation and hand moves. Excerpts of the session in which participants' utterances reflect immediate responsivity tend to correspond to moments of mutual eye gazing (that is, both participants look for each other's and self image on the computer screen as they speak not to the camera itself). On the other hand, excerpts of the session in which participants' utterances reflect non-immediate responsivity more often account for rather indefinite 
eye orientation (e.g. participants look at printed material on the desk or lack visual contact with the partner due to technical problems).

When one participant sees the other on the screen, she can also see herself as well as to notice that she is seen by the other (that is how eye gazing could be described in this context). Since all the meanings shared through verbal spoken language are constructed under the perspective that both speakers recognize what each other look like simultaneously, meanings are enriched and communication is boosted compared to moments when participants do not perform mutual eye gazing. In fact, immediate responsivity usually correlates to mutual eye gazing on the interaction timeline.

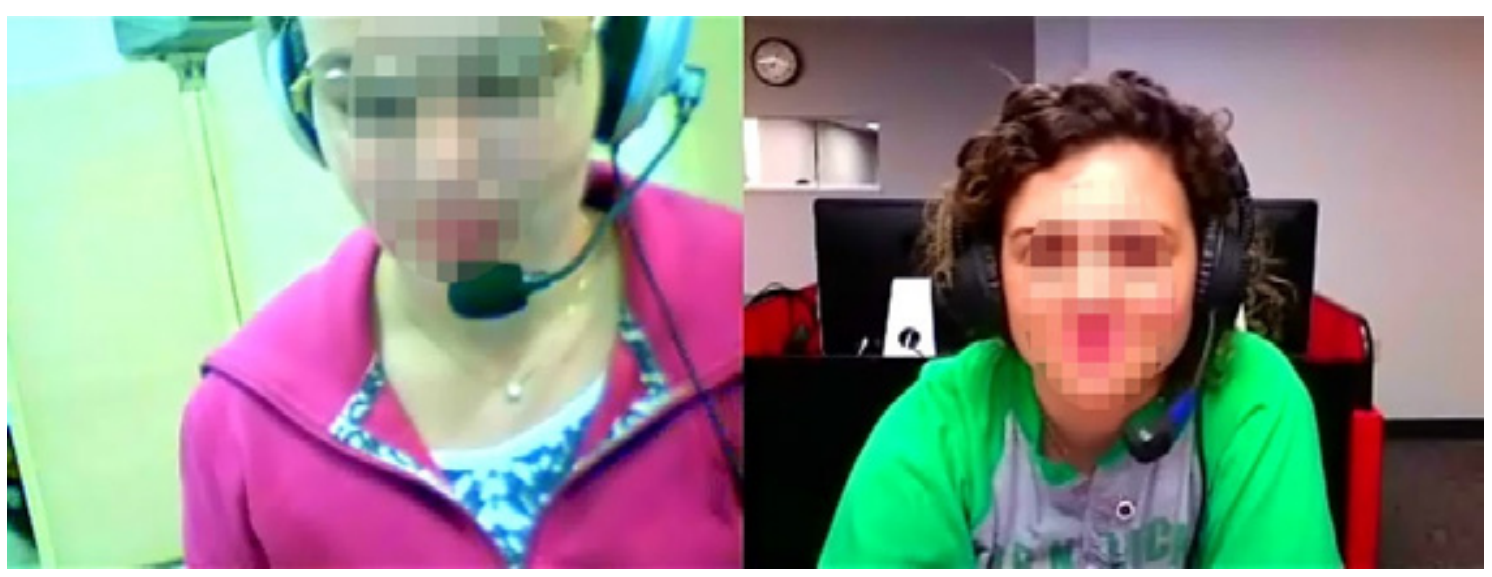

Figure 4. How webcams frame practitioners

Figure 4 (a screen capture), above, is a sample of how the two practitioners are framed by their webcams as well as of the cinematic images both of them can see onscreen. The screen capture was taken during oral session 1. At that moment, conversation showed signs of prevailing immediate responsivity while the two participants kept their eyes gazed towards the computer screen, which enables them to see each other, see their own image and, furthermore, perceive whether they are seen by the interlocutor or not.

\section{Some conclusions and final remarks}

In this paper, we reported on an investigation on occurrences of both verbal and non-verbal language as produced by TTDii practitioners, illustrated by an initial description of how turn taking, topic maintenance and duration may occur. The selection of data samples and the discussion were grounded on a theoretical framework about intersubjectivity based on Bakhtin's dialogism (Bakhtin, 2006). Two perspectives included in the discussion about intersubjectivity were considered, one of an operational nature 
- | Understanding teletandem language learning from an intersubjective perspective

in order to describe how intersubjectivity is established, and a rather metaphysical perspective to allow the pursuit of relations between the establishment of intersubjectivity and language use, as well as language development towards linguistic competence in foreign languages.

We have so far concluded that turn duration and topic maintenance may correlate with the extent of the interaction in which internal responsivity prevails. When participants succeed in developing more immediate responsivity, their conversation turns are often longer, more meaningful and they approach the topic in a more interested manner (so no new topic is immediately necessary to keep the conversation active). Besides, in these circumstances, learner practitioners less often express difficulty in understanding or uttering in their target language.

As for visual communication and body language, the data indicate that the more evident and varied body language is - that is, non-verbal language which interactants produce, sometimes together with verbal language, and which is meaningfully perceived - the better communicative conditions are established. Particularly, moments in which both participants address their visual attention to the computer screen - that is, the space where the two cinematic images are displayed - often correlate to fragments of the oral session when the dialogue quality is raised. Mutual visual perception via webcam can be understood as part of an aesthetic recognition process that accounts for the construction of interlocutors' corporealty and intersubjectivity.

We tend to believe that occasions of more immediate responsivity and longer turns indicate not only engagement on the part of the practitioners but also more confidence and higher levels of language proficiency. Both verbal language and mutual vision perception contribute to the establishment of intersubjectivity and may therefore favor language practice that can lead towards language development.

\section{References}

ARANHA, S.; CAVALARI, S. M. S. A trajetória do projeto Teletandem Brasil: da modalidade institucional não-integrada à institucional integrada. The ESPecialist, v. 35, n. 2, p. 183-201, 2014.

BAKHTIN, M. Estética da Criação Verbal. Tradução Paulo Bezerra. 4. ed. São Paulo: Martins Fontes, 2015. 
- | Understanding teletandem language learning from an intersubjective perspective

BENJAMIN, W. Linguagem | Tradução | Literatura (filosofia, teoria e crítica). Lisboa, Portugal: Porto Editora, 2015.

CAVALARI, S. M. S.; ARANHA, S. Teletandem: integrating e-learning into foreign language classroom. Acta Scientiarum - Language and Culture, Maringá, v. 38, n. 4, p. 327-336, 2016.

DURANTI, A. Husserl, intersubjectivity and anthropology. Anthropological theory, v. 10, n. 1, p. 16-35, 2010.

HEIDEGGER, M. Ser e verdade: a questão fundamental da filosofia; da essência da verdade. Tradução Emmanuel Carneiro Leão. Petrópolis: Editora Vozes; Bragança Paulista: Editora Universitária São Francisco, 2007.

HUSSERL, E. Méditations Cartésiennnes. Tradução E. Lévinas e G. Peiffer. Paris: Vrin, 1969 [1929].

MCCAFFERTY, S. G. Gestures and creating zones of proximal development for second language learning. Modern Language Journal, n. 86, p. 192-203, 2002.

MELTZOFF, A. N.; BROOKS, R. Intersubjectivity before language: Three windows on preverbal sharing. In: BRÅTEN, S. (ed.). On being moved: From mirror neurons to empathy. Philadelphia, PA: John Benjamins, 2007. p. 149-174.

MELTZOFF, A. N.; MOORE, M. K. Object representation, identity and the paradox of early permanence: Steps toward a new framework. Infant Behavior and Development, v. 21, p. 201-235, 1998.

MERLEAU-PONTY, M. Le primat de la perception. Paris: Verdier, 1996 [1946].

MORI, J.; HAYASHI, M. The Achievement of Intersubjectivity through Embodied Completions: A Study of Interactions Between First and Second Language Speakers. Oxford: Oxford University Press, 2006.

MÖTTÖNEN, T. Construal in Expression: Intersubjective Approach to Cognitive Grammar. Ph.D. dissertation. University of Helsinki, 2016. 
- | Understanding teletandem language learning from an intersubjective perspective

SAMBRE, P. Fleshing out language and intersubjectivity: an exploration of Merleau-Ponty's legagy to cognitive linguistics. Journal of Cognitive Semiotics, v. IV, n. 1, p. 189-224, 2012.

SCHELER, M. Nature et formes de la sympathie. Tradução M. Lefebvre. Paris: Payot, 1971.

TELLES, J. A. Teletandem: A transculturalidade das interações on-line em línguas estrangeiras via teleconferência. Paper presented at the IX CBLA - Congresso Brasileiro de Linguística Aplicada (Brazilian Conference of Applied Linguistics), Rio de Janeiro, Brazil: UFRJ - Universidade Federal do Rio de Janeiro, 2011.

VYGOTSKI, L. S. Obras Escogidas. Madrid: Apredizaje/Visor, 1995.

ZLATEV, J. The coevolution of intersubjectivity and bodily mimesis. In: ZLATEV, J.; RACINE, T.; SINHA, C.; ITKONEN, E. (ed.). In The Shared Mind: Perspectives on Intersubjectivity. Amsterdam: Benjamins, 2008. p. 215-244.

ZLATEV, J. Intersubjectivity, mimetic schemas and the emergence of language, Intellectica, v. 2-3, p. 123-152, 2007.

COMO CITAR ESTE ARTIGO: SANTOS, Gerson Rossi dos; CONSOLO, Douglas Altamiro. Understanding teletandem language learning from an intersubjective perspective. Revista do GEL, v. 15, n. 3, p. 324-343, 2018. Disponível em: https://revistadogel.gel.org.br/

DOI: http://dx.doi.org/10.21165/gel.v15i3.2396

Submetido em: 09/11/2018 | Aceito em: 28/12/2018. 